\title{
The Effect of Transformational Leadership Style on Job Satisfaction with Trust-In-Leader as Intervening Variable
}

\author{
Muslichah $^{1}$, Sobikhul Asrori ${ }^{1}$
}

\author{
STIE Malangkucecwara, Malang, Indonesia ${ }^{1}$
}

\begin{abstract}
This research was aimed to analyze direct and indirect effects of transformational leadership style on job satisfaction. The population of research included all employees at the Local Secretariat Office of Pasuruan Indonesia, which was counted for 170 persons. A questionnaire was distributed to this population, and 151 questionnaires were returned, which thus resulting in a response rate of $88.82 \%$. Data analysis procedure is path analysis facilitated by a PLS computer software. Results indicated that: 1) There is a direct, positive and significant effect of transformational leadership style on job satisfaction; 2) There is a direct, positive, and significant effect of transformational leadership style on trust-inleader; 3) There is a direct, positive, and significant effect of trust-in-leader on job satisfaction; 4) Trust-in-leader mediates the effect of transformational leadership style on job satisfaction. Given all these findings, this research not only has a good implication on practice but also to the literature concerning the effect of both transformational leadership style and trust-in-leader on job satisfaction. It is also expected that this research provides information that can be used as guidance by the Local Secretariat Office in Pasuruan City Indonesia when it decides to improve employee's job satisfaction.
\end{abstract}

Keywords: Transformational leadership style; trust-in-leader; job satisfaction.

\section{Introduction}

Human resource is a resource that helps an organization to mobilize other resources. Empowering organizational human resource is a very important action that must need a proper leadership style to ascertain the achievement of organizational goals. Leadership style indeed determines the success of an organization. A leader should motivate and encourage his employees to work on a predetermined concept, including giving praise, recognition, and motivation to the employees. One of a leadership style that influences job satisfaction is transformational leadership (Puni et al., 2018; Braun et al., 2012). Bass (1990) defined that transformational leadership is evident when a leader has a capacity to convince followers in certain ways. Transformational leadership allows a leader to receive trust, respect, loyalty, and responsiveness from the followers.

One important element to increase job satisfaction of employees is that leader must be able to give a proper direction for the followers to ascertain the achievement of the expected organizational goals. Employees with high job satisfaction tend to work harder at a job (Pushpakumari, 2008). Job satisfaction is a matter of individual because everyone always has a different rate of job satisfaction. The fitter is a job to individual interest, the higher will be job satisfaction. Some factors influence job satisfaction, and among others are leadership style and trust-in-leader. Leadership is a dynamic component that determines job satisfaction and organizational performance (Elbaz \& Haddoud, 2017). Effective leadership style is a factor producing employee's job satisfaction. The most studied leadership style is transformational leadership (Yaghoubipoor et al., 2013; Liu, Siu, \& Shi, 2010). Few earlier studies said that transformational leadership has successfully produced the expected individual behavior (Judge \& Piccolo, 2004; Liu, Siu, \& Shi, 2010). Other studies found that transformational leadership has a significant and positive effect on employee's job satisfaction (Bushra, Ahmad, \& Navee, 2011; Munir, Rahman, Malik, \& Ma'amor, 2012; Nanjundeswaraswamy \& Swamy, 2014; Saleem, 2015; Jyoti \& Bhau, 2016).

Trust is a foundation of a relationship. It plays important role in relationship between leader and follower. This relationship can be successful when there are trust and openness. Trust-in-leader develops when followers sense that their leader can be trusted and is willing to give them benefits. The higher is trust-in-leader, the higher will be employee's job satisfaction. Trust-in-leader elicits a higher level of creativity and enthusiasm at work, and the next result is job satisfaction. Previous studies showed that trustin-leader has a positive and significant effect on job satisfaction (Saputra, 2013; Syarifah et al., 2016).

This research attempts to replicate and extend the previous studies. The differences between the current research and the previous are threefold. Firstly, the object examined by previous studies include

\footnotetext{
${ }^{1}$ muslichahmachali@yahoo.com
} 
travel agent (Elbaz \& Haddoud, 2017), higher education (Braun et al., 2012; Saleem, 2015, Alonderiene \& Majauskaite, 2015), and manufacture firms (Tee dan Ahmed, 2013). The current research is done at the local governmental office, precisely at the Secretariat Office in Pasuruan Indonesia. After more than three decades under a centralized national government, Indonesia decided to implement a new policy of regional autonomy. Suryono (2004) states that the leadership skill of local government officials are very important in realizing the regional autonomy program.

Secondly, many studies have invertigated the relationship between transformational leadership and job satisfaction. However very little work has been done on the relationship between transformational leadership on trust in leader (Lu, Siu \& Shi, 2010; Braun et al., 2012). Thirdly, there are substantial volume of research that examines the effect of transformational leadership on job satisfaction, however, the results are still inconsistent. For example, researchers (Boamah et al., 2018; Saleem, 2014; Braun et al., 2012 ) have shown strong positive relationship between transformational leadership and job satisfaction. Conversely, research conducted by Thamrin (2012) found that transformational leadership negatively affects job satisfaction. The inconsistency shows that there might be another variable influence the relationship between the two variables. Previous studies have suggested that trust in the leader is one of a mediators between transformational leadership and followers' outcomes (Pillai \& Williams, 2004). In the leadership literature, trust is a mediator variable in the relationship between the various variables in organizational behavior (Yanik, 2018; Gilstrap and Collins,2012).

This research has two objectives. First is to analyze direct effect of transformational leadership style on job satisfaction, while the second is to examine the indirect effect of transformational leadership style on job satisfaction through trust-in-leader.

\section{Literature Review Transformational Leadership}

Leadership theory was firstly suggested by Burns (1978), and then it was revitalized by Bass (1978) in Charles R. Emery \& Kathrine Barker (2007). Bass identified two types of political leadership, respectively transformational leadership, and transactional leadership. Transformational leadership is defined as a leadership type in which leader changes values, trust, attitude, behavior, emotion, and demand of the followers into the better orientation in the future.

Robbins (2008:464) asserted that transformational leadership is a leadership type in which leader inspires followers to prioritize organizational progress over personal interest, gives great attention to the welfare of the followers, and modifies followers' conscience to persuade them to solve an old problem with the new method. It can also be said that transformational leadership style is a leadership type that compels followers to keep side their interest, and this leadership type is very persuasive.

Transformational leadership is marked by four dimensions, namely: idealized influence, inspirational motivation, individualized consideration, and intellectual stimulation (Bass \& Avolio, 1993:112; Bass, 1997:21; Bass et al., 2003:208). Bass \& Avolio proposed these four dimensions (also known as "4I") of transformational leadership. Bass also suggested that transformational leader shall gain trust, respect, and amazement from the followers.

Each dimension of transformational leadership will be explained further. The first dimension is an idealized influence. In this dimension, the leader becomes a role-model for the followers from which leader will be respected and trusted by followers (Bass \& Riggio, 2006). The second dimension is inspirational motivation. A leader inspires and motivates followers by giving them work challenge (Bass \& Riggio, 2006). The third dimension is an individualized consideration, where leader put great attention to followers' demand for achievement and development, and is willing to be become a mentor or trainer to them (Bass \& Riggio, 2006). The fourth dimension is intellectual stimulation. As said by Bass, in this dimension, followers feel that leader allows them to evaluate their job method from which they look for a new way in understanding the job, and finish the job with a new method (Munandar, 2008; Spector, 2012).

\section{Job Satisfaction}

Job satisfaction, according to Aziri B. (2011) is basically one of the psychological aspects that reflects a person's feelings toward his work. The higher one loves his job, the higher the job satisfaction (Danicac, 2016). Robbins (2007) said that job satisfaction is a reasonable attitude of an individual to the job. The individual with higher job satisfaction shows a positive attitude to the job, while an individual with lower job satisfaction expresses negative feeling on the job (Robbins and Judge, 2017). Job satisfactions can be defined as "the attituted and feelings people have about their work. Positive and favorable attitudes towards the job indicate job satisfaction. Negative and unfavorable attitudes towards the job indicate job dissatisfaction" (Armstrong, 2006). 
Robbins (2007) distinguishes five attributes of job satisfaction. The first attribute is the job itself. A lucrative job that fits individual interest shall produce job satisfaction. The second is salary, which is considered as a device to fulfill livelihood. Whether it is fair or not depends on employee's judgment. Fringe benefits can also increase job satisfaction. The third attribute is promotion, and employees consider it as very important because it helps them to progress forward in the organization. The fourth is leader's attention. A leader who is attending followers' wellbeing and motivating them into the better person is a good leader. Finally, the fifth attribute is the presence of job group or job partner that is cooperative at work. It gives employees a job satisfaction because it provides them with support, convenience, advice, and assistance at work.

\section{Trust-in-Leader}

Trust is an important factor that determines followers' satisfaction on a leader. Trust is defined "as an expectation or belief that one can rely on another person's actions and words and that the person has good intentions to carry out their promises" (Bligh, 2017). trust can be viewed as a willingness to rely on others by expecting that they will give in return the favor given previously. It represents a capacity of being cooperative, and it is needed in the relationship between leader and followers. The reason is obvious because followers can not develop trust in leader unless the leader can fulfill a leadership role.

Five dimensions are identified as constituting trust concept (Schindler and Thomas, 1993): 1) integrity, which is indicated by honesty dan thruthfulness; 2) competency, which is related with knowledge and skills concerning technicality and interpersonality; 3) consistency, which is measured by dependability, predictability, and good consideration in dealing with issues; 4) loyalty, which refers to a willingness to protect and save other's face; and 5) openness, which stands for a willingness to take a liberty to share ideas and information.

McAllister (1995) identifies that there are two types of trust, namely affect-based trust, and cognitive-based trust. Regarding affect-based trust, it is a preference to believe one's good intention and integrity, and also to be convinced about having a reciprocal relationship in the future. Meanwhile, cognitive-based trust is a tendency to believe the capacity and competency of co-workers. Both types of trust involve belief and respect for other individuals because the evidence of competency, accountability, and dependability are used as the criteria to judge whether the trust is deserving or not.

\section{Methodology}

Type of research is quantitative study. This study used questionnaire to gather information regarding variables under study. The population of this research includes all employees working at the Local Secretariat Office of Pasuruan City Indoesia. These employees are spread on 10 Division Units and ounted for 170 persons. These employees are given structured questionnaires in Indonesian languange. The questionnaire is divided into two sections, first section is demographic profile of respondents, and second section is variables under study, namely transformational leadership, trust-in leader,and job satisfaction. The authors distributes 170 questionnaires, but only 151 persons complete and return questionnaire sheet, which results in a response rate of $88.82 \%$.

\section{The influence of Transformational Leadership Style on Job Satisfaction}

Transformational leaders affects employee job satisfaction because this type of leadesr able to motivate their employees (Yaghoubipoor et al., 2013). Transformational leaders can provide exemplary role models for their employees, can encourage employees to behave creatively, innovatively and able to solve problems with new approach. A transformational leader encourages employees to participate in decision-making processes, which in turn can improve critical thinking, skills development and knowledge. Such leaders will be able to empower employees through the support, information, and resources available, this will create positive reaction from employees (Boamah et al.,2018). Furthermore, Saleem (2014) asserted that transformational leader behaves to inspire and motivate followers to do something, which initiates the change in psychological conditions of organizational members but still with job satisfaction as the ultimate goal. Previous studies showed that transformational leadership has a significant and positive effect on job satisfaction (Voon et al., 2011; Munir et al., 2012; Nanjundeswaraswamy \& Swamy, 2014; Saleem, 2015; Jyoti \& Bhau, 2016). Under elaborations given above, the following hypothesis is Hypothesis 1 (H1): Transformational leadership style has a positive effect on job satisfaction.

\section{The Effect of Transformational Leadership Style on Trust-in-Leader}

Transformational leadership style requires a leader to engage closely with followers (Avolio et al., 1991). The important thing that underlies transformational leadership is that people will follow leaders who 
inspire and motivate them. Burns (1978) describes a transformational leader as one that identify the potential motives of his followers, striving to meet their needs and engaging followers in every process of change. This kind of transformational leader behavior could be related to trust in leader. Bass (1998) states that transformational leaders motivate followers to achieve more than originally planned. The leaders are also able to create a good organizational climate in which individual needs and differences are recognized and respected. Transformational leaders share goals that enable leaders and followers to focus on the common good, through commitment to the mission and organizational values. This can create a climate of openness and trust (Menon, 2014). Transformational leadership style strengthens the emotional bonding between leader and followers, and this increases trust-in-leader (Dirks \& Ferrin, 2002; Jung \& Avolio, 2000). Previous studies indicated that transformational leadership style has a positive effect on trust-inleader (Schaubroeck et al., 2011; Braun et al., 2012). Based on the explanations above, a hypothesis is written as Hypothesis 2 (H2): Transformational leadership style has a positive effect on trust-in-leader.

\section{The Effect of Trust-in-Leader on Job Satisfaction}

Trust in the leader can enhance positive feelings reduce negative feelings (Laida, 2013). The definition of trust that has been widely used in organisational research is "The willingness of a party to be vulnerable to the actions of another party" (Schoorman, Mayer, \& Davis, 2007). The definition based on three factors of perceived trustworthiness, namely: ability, benevolence, and integrity (Mayer et al., 1995). Employees feel more secure and comfortable if their leaders have the three factors (Braun et al., 2012). Both senses of security and comfort could increase followers' positive feelings toward their leaders. Furthermore, Dirks \& Ferrin (2002) states that followers will trust their leaders if they gives care and consideration. If subordinates believe that their leader is trustworthy they will psychologically have positive feelings towards their leardes, which ultimately affects his job satisfaction (Dirks \& Ferrin, 2002). Regarding the description above, the following hypothesis is Hypothesis 3 (H3): Trust-in-leader has a positive effect on job satisfaction.

\section{The influence of Transformational Leadership Style on Job Satisfaction with Trust-in-Leader as Mediation Variable}

Transformational leaders who actively promote individual followers' progress and involvement signal their ability to lead as well as their benevolence and integrity, and will therefore elicit higher levels of trust. Followers who trust their leader will be more satisfied in their jobs (Yang \& Mossholder, 2010) because they experience high levels of care and consideration.

Trust in the leader has been a significant outcome built by effective leadership, especially in the field of TL (e.g. Casimir, Waldman, Bartram, \& Yang, 2006; Jung \& Avolio, 2000; Pillai et al., 1999; Podsakoff et al., 1990). Yukl (1999) argued that one of the key reasons why transformational leadership works is followers' trust and respect. Transformational leaders may gain followers' trust by acting as role models in the process of developing a shared vision, and also by demonstrating individualised consideration for followers' needs and the capability to achieve the vision. Given the explanation above, the following hypothesis is Hypothesis 4 (H4): Transformational leadership style has a positive effect on job satisfaction with trust-in-leader as mediation variable.

Taking into account all descriptions of the variable in previous sections, then research model can be arranged as follows:

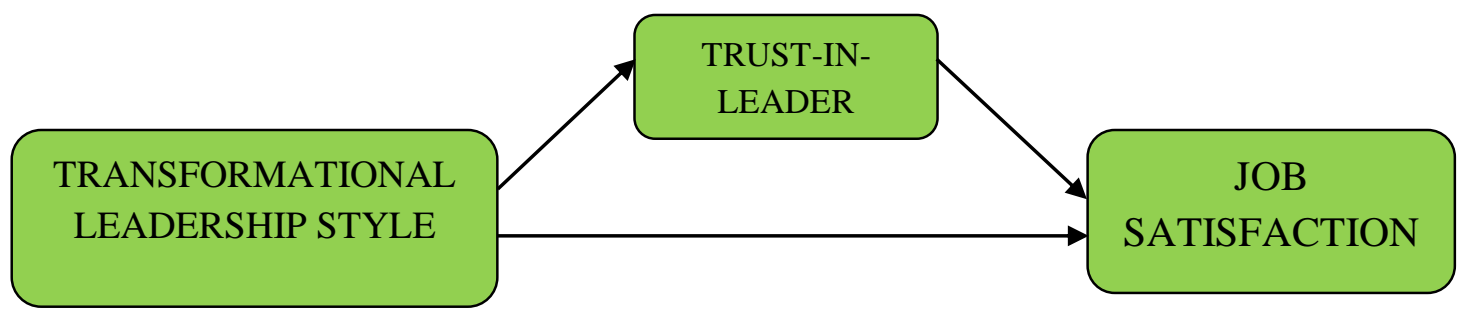

\section{Result and Discussion}

Figure 1. Research Model

Table 1 presents the demographic profile of 151 respondents who participated to this study. The profile includes age, gender, educational background, and tenure. 


\begin{tabular}{|c|c|c|}
\hline \multicolumn{3}{|c|}{ Table 1. Respondent Profile } \\
\hline Description & Number & Percentage \\
\hline \multicolumn{3}{|l|}{ Age } \\
\hline 20-29 years & 19 & $12.6 \%$ \\
\hline 30-39 years & 69 & $45.7 \%$ \\
\hline $40-49$ years & 40 & $26.7 \%$ \\
\hline $50-50$ & 23 & $15.2 \%$ \\
\hline Total & 151 & $100 \%$ \\
\hline \multicolumn{3}{|l|}{ Gender } \\
\hline Male & 82 & $54.3 \%$ \\
\hline Female & 69 & $45.7 \%$ \\
\hline Total & 151 & $100 \%$ \\
\hline \multicolumn{3}{|l|}{ Highest Education } \\
\hline Elementary/Secondary/High School & 60 & $39.7 \%$ \\
\hline Diploma & 14 & $9.3 \%$ \\
\hline Bachelor & 57 & $37.7 \%$ \\
\hline Master/Doctorate & 20 & $13.2 \%$ \\
\hline Total & 151 & $100 \%$ \\
\hline \multicolumn{3}{|l|}{ Tenure } \\
\hline $1-5$ years & 26 & $17.2 \%$ \\
\hline 6-10 years & 37 & $24.5 \%$ \\
\hline $11-15$ years & 46 & $30.5 \%$ \\
\hline $16-20$ years & 17 & $11.3 \%$ \\
\hline $21-25$ years & 14 & $9.3 \%$ \\
\hline$>25$ years & 11 & $7.3 \%$ \\
\hline Total & 151 & $100 \%$ \\
\hline
\end{tabular}

Source: Primary data processed.

Table 1 shows that most respondents are aged at 30-39 years as justified with a percentage of 45.7\%. A number of a male respondent is $54.3 \%$, which is more than female respondent that is shown by the percentage of $45.7 \%$. Also, respondents are mostly graduated from elementary and high school with a percentage of $39.7 \%$. The longest tenure of respondents is $11-15$ years as indicated by the percentage of $30.5 \%$.

\section{Hypothesis Test}

A hypothesis test is aimed to analyze the relationship by calculating path coefficient of each path (path analysis). The analysis of relationship begins only after resampling. The process of resampling is done by using bootstrapping method to minimize research data's abnormality. A base material for hypothesis test using Smart PLS Version 2.0 is the output of path coefficient. Statistic value is involved to indicate the position of the hypothesis. T-table at alpha $5 \%$ is 1.96 . The hypothesis is accepted when Tstatistic > T-table.

Table 2. Path Coefficient, Mean, STDEV, T-Values

\begin{tabular}{|c|c|c|c|c|c|c|}
\hline & $\begin{array}{l}\text { Original } \\
\text { Sample } \\
(\mathrm{O})\end{array}$ & $\begin{array}{l}\text { Sample } \\
\text { Mean } \\
(\mathrm{M})\end{array}$ & $\begin{array}{l}\text { Standard } \\
\text { Deviation } \\
(\mathrm{STDEV})\end{array}$ & $\begin{array}{l}\text { T-Statistic } \\
(|\mathrm{O} / \mathrm{STERR}|)\end{array}$ & $\begin{array}{c}\text { T- } \\
\text { Table }\end{array}$ & SIG \\
\hline $\begin{array}{l}\text { Transformational leadership } \\
\rightarrow \text { trust-in-leader }\end{array}$ & 0.825337 & 0.828837 & 0.030992 & 26.630548 & 1.97623 & 0.00000 \\
\hline $\begin{array}{l}\text { Transformational leadership } \\
\rightarrow \text { Job satisfaction }\end{array}$ & 0.418911 & 0.429230 & 0.124684 & 3.359786 & 1.97623 & 0.00099 \\
\hline $\begin{array}{l}\text { Trust-in-leader } \rightarrow \quad \text { Job } \\
\text { satisfaction }\end{array}$ & 0.287099 & 0.283171 & 0.141618 & 2.027275 & 1.97623 & 0.04444 \\
\hline
\end{tabular}


Based on Path Coefficient presented in table above, different t-statistic values are obtained. Therefore, the analysis on each hypothesis can be elaborated as follows:

\section{H1: Transformational Leadership Style has a positive effect on Job Satisfaction.}

Under the output of path coefficient in Table 2, it is shown that the effect of transformational leadership style on job satisfaction is significant, as indicated by T-statistic (3.359786) > T-table (1.97623) and significance value of $0.00099<0.05(\alpha=5 \%)$. The estimated value of the original sample is 0.418911 , which means that the direction of the relationship between transformational leadership style and job satisfaction is positive. Thus, $\mathrm{H} 1$ is accepted.

\section{H2: Transformational Leadership Style has a positive effect on Trust-in-Leader.}

Based on the output of path coefficient in Table 2, it is shown that the effect of transformational leadership style on trust-in-leader is significant, as indicated by T-statistic (26.630548) > T-table (1.97623) and significance value of $0.00000<0.05(\alpha=5 \%)$. The estimated value of the original sample is 0.825337 , which means that the direction of the relationship between transformational leadership style and job satisfaction is positive. Therefore, $\mathrm{H} 2$ is no rejected.

\section{H3: Trust-in-Leader has a positive effect on Job Satisfaction.}

Regarding the output of path coefficient in Table 2, it is indicated that the effect of trust-in-leader on job satisfaction is significant, as shown by T-statistic (2.027275) > T-table (1.97623) and significance value of $0.04444<0.05(\alpha=5 \%)$. The estimated value of the original sample is 0.287099 , which means that the direction of the relationship between trust-in-leader and job satisfaction is positive. Therefore, H3 is supported.

\section{H4: Transformational Leadership Style has a positive effect on Job Satisfaction with Trust-in-Leader as Mediation Variable.}

As shown in Table 2 above, the effect of transformational leadership style on trust-in-leader is direct and significant as shown by T-statistic (3.359786) $>$ T-table (1.97623) and significance value of $0.00099<0.05(\alpha=5 \%)$. The table also indicates that the effect of trust-in-leader on job satisfaction is significant as shown by T-statistic (2.027275) > T-table (1.97623) and significance value of $0.04444<0.05$ $(\alpha=5 \%)$. Furthermore, the result of Sobel Test gives significance value of $0.02161505(<5 \%)$, which proves that trust-in-leader mediates the effect of transformational leadership style on job satisfaction. In relation to this finding, $\mathrm{H} 4$ is accepted.

Transformational leadership style can affect job satisfaction directly, or indirectly through mediation of trust-in-leader. Transformational leadership style is more proactive and more effective in motivating followers to achieve better performance. A transformational leader provides followers with role-model that stimulates them to express creative and innovative behaviors, and solve a problem with a new approach. Transformational leader attends to followers' wellbeing and motivates them to increase performance, and this is where job satisfaction develops (Bushra, Ahmad, \& Navee, 2011; Munir, Rahman, Malik, \& Ma'amor, 2012; Nanjundeswaraswamy \& Swamy, 2014; Saleem, 2015; Jyoti \& Bhau, 2016).

The results of this study indicate that job satisfaction of employees at the Local Secretariat Office can be increased by applying transformational leadership style and improving followers' trust-in-leader. Transformational leader must convince followers that their performance and target achievement are important for their goodness and organization where they work. Transformational leader shall persuade followers to think about moral and ethical consequences of any decisions they have made. Transformational leader shall give more weights on some issues, such as: emphasizing the importance of optimism to the future of an organization, building enthusiasm to achieve organizational goals and targets, giving new advice on how to accomplish the job, understanding problem from different angles, and providing direction for followers/employees. Concerning with how to increase followers' trust-in-leader, a leader at the Local Secretariat Office of Pasuruan City must conserve direct communication with followers to create emotional bonding among them.

Trust-in-leader mediates transformational leadership style and job satisfaction. It is consistent with Braun et al. (2013). Functions of a transformational leader are to motivate, inspire, and improve followers' performance. Creativity may grow when transformational leadership style is used. The success of transformational leadership style depends on whether followers trust their leader (Berntson et al., 2012). Trust-in-leader determines the success of job relationship between leader and followers (Yang \& Mossholder, 2010). Followers who trust their leader are motivated to perform extra jobs, willing to complete difficult jobs, and eager to sacrifice personal interest for the achievement of leader's expected 
goals (Pillai et al., 2011). Trust in the relationship between leader and followers can increase job satisfaction, commitment, and organizational success (Pereira \& Gomes, 2012).

\section{Conclusions, suggestions and limitations}

Four important findings are delivered by this research. (1) Transformational leadership has a positive and significant effect on job satisfaction; (2) Transformational leadership style has a positive and significant effect on trust-in-leader; (3) Trust-in-leader has a positive and significant effect on job satisfaction; and (4) Trust-in-leader mediates the effect of transformational leadership style on job satisfaction.

The paper makes an important contribution to the existing organizational literature by establishing trust-in-leader as a intervening variable on the relationship between transformational leadership and job satisfaction in a public sector. Theoretically, employee job satisfaction can be achieved if leaders are of the right transformational style and providing both task and relation support to the employees. The main practical implication of this study is that transformational leaders should take trust-in-leader into account, doing so has consequences for job satisfaction. Practically, results of this study can be applied to public sector because public sector employees, to a large extent, rely on the socio-emotional support and recognition of transformational leader to build long-term and close interactive relationship with cowokers and society.

The limitation of this research is that it only examines employees at the Local Secretariat Office of Pasuruan Indonesia. Further research shall enhance the coverage by including more public offices and involving more respondents from which the result can be generalized to the other context. In addition to the questionnaire, there are other techniques that can be exploited to collect the data, such as deep interview and observation. The current research only develops the relationship between transformational leadership style and job satisfaction with trust-in-leader as mediation variable. Further research can involve other variables where transformational leadership style can be connected with few dependent variables such as job motivation, employee performance, turnover intention, and organizational commitment.

\section{References}

Alonderiene, Raimonda, Modesta Majauskaite, (2016) Leadership style and job satisfaction in higher education institutions, International Journal of Educational Management, Vol. 30 Issue: 1, pp.140164

Armstrong, M. (2006). A Handbook of Human resource Management Practice, Tenth Edition, Kogan Page Publishing, London, , p. 264

Avolio, B. J., Bass, B. M., and Jung, D. I., (1999), Re-Examining The Components of Transformational and Transactional Leadership Using The Multifactor Leadership Questionnaire, Journal of Occupational and Organizational Psychology. Vol. 2, No. 4, pp. 441-462.

Aziri, Brikend. (2011) Ajob Satisfaction: A Literature Review, Management Research and Practice, Vol. 3 Issue 4, pp: 77-86.

Bass, B.M., 1990. From Transactional to Transformational Leadership: Learning to Share the Vision. Organizational Dynamics; Winter 90, Vol. 18 Issue 3, p19

Bass, B. M., \& Riggio, R. E. (2006). Transformational leadership (2nd Ed.). New Jersey: Lawrence Erlbaum Associates.

Berntson, E., Wallin, L., \& Härenstam, A. (2012). Typical situations for managers in the Burns, J. (1978). Leadership. New York: Harper and Row. Swedish public sector: Cluster analysis of working conditions using the job demands-resources model. International Public Management Journal, 15(1), 100-130.

Bligh, Michelle C.(2017). Leadership and Trust, Springer International Publishing Switzerland.

Burke, C. S., Sims, D. E., Lazzara, E. H., \& Salas, E. (2007). Trust in leadership: A multi-level review and integration. The Leadership Quarterly, 18, 606-632

Braun, Susanne, Claudia Peus, Silke Weisweiler, Dieter Frey (2012), Transformational leadership, job satisfaction, and team performance: A multilevel mediation model of trust, The Leadership Quarterly 24 (2013) 270-283

Bushra, F., Ahmad, U., \& Naveed, A. (2011). Effect of transformational leadership on employees' job satisfaction and organizational commitment in banking sector of Lahore (Pakistan). International Journal of Business and Social Science, 2(18), 261-267.

Burns, J. (1978), Leadership, Harper \& Row, New York, NY 
Charles R. Emery and Kathrine Barker. (2007). The Effect of Transactional and Transformational Leadership Styles on the Organizational Commitment and Job Satisfaction of Customer Contact Personnel. Journal of Organizational Culture, Communications, and Conflict, Vol, 11, No. 1, pp. 227-242

Chun, J. U., Yammarino, F. J., Dionne, S. D., Sosik, J. J., \& Moon, H. K. (2009). Leadership across hierarchical levels: Multiple levels of management and multiple levels of analysis. The Leadership Quarterly, 20, 689-707

Danica Bakotić (2016) Relationship between job satisfaction and organisational performance, Economic Research-Ekonomska Istraživanja, 29:1, 118-130

Dirks, K. T., \& Ferrin, D. L. (2002). Trust in leadership: Meta-analytic findings and implications for research and practice. Journal of Applied Psychology, 87, 611-628,

Elbaz, A. M., \& Haddoud, M. Y. (2017). The role of wisdom leadership in increasing job performance: Evidence from the Egyptian tourism sector. Tourism Management, 63, 66-76.

Gilstrap, J. B., Collins, B. J. (2012). The Importance of Being Trustworthy: Trust as a Mediator of the Relationship between Leader Behaviors and Employee Job Satisfaction, Journal of Leadership \& Organizational Studies, Vol. 19, No. 2, 152-163

Judge, T. A., \& Piccolo, R. F. (2004). Transformational and transactional leadership: A meta-analytic test of their relative validity. Journal of Applied Psychology, 89, 755-768

Jung, D. I., \& Avolio, B. J. (2000). Opening the black box: An experimental investigation of the mediating effects of trust and value congruence on transformational and

transactional leadership. Journal of Organizational Behavior, 21, 949-964

Jyoti, J., \& Bhau, S. (2016). Empirical investigation of moderating and mediating variables in between transformational leadership and related outcomes: A study of higher education sector in North India. International. Journal of Educational Management, 30(6), 1123-1149

Laida, Agote Errazquin, (2013). Authentic Leadership, Trust and Followers' Emotions: The Experience of HRMs During Organizational Change Processes, Azkoaga, 16, 123-148.

Liu, J., Siu, O. L., \& Shi, K. (2010). Transformational leadership and employee well-being: The mediating role of trust in the leader and self-efficacy. Applied Psychology: An International Review, 59, 454479.

McAllister, D. J. (1995). Affect- and connection based trust as foundations for interpersonal advantage. Academy of Management Journal, 38(1), 24-59.

Munir, R. I. S., Rahman, R. A., Malik, A. M. A., \& Ma'amor, H. (2012). Relationship between transformational leadership and employees' job satisfaction among the academic staff. ProcediaSocial and Behavioural Sciences, 65(2012), 885-890.

Munandar A.S. (2008) Psikologi Industri \& Organisasi Jakarta : Penerbit Universitas Indonesia.

Nanjundeswaraswamy, T. S., \& Swamy, D. R. (2014). Leadership styles. Advances in Management, 7(2), 57-62.

Pereira, C. M. M., \& Gomes, J. F. S. (2012). The strength of human resource practices and transformational leadership: impact on organizational performance. International Journal of Human Resource Management, 23(20), 4301-4318

Pillai, R., Kohles, J.C., Bligh, M.C., Carsten, M.K., \& Brodowsky, G. (2011). Leadership in Confucian Asia: A three-country study of justice, trust, and transformational leadership. Organization Management Journal, 8(4), 242-259.

Pushpakumari, M.D (2008), Impact of Job Satisfaction on Employees Performance. Arabian Journal of Business and Management Vol. 7(8):89-105

Podsakoff, Philip M., Scott B. Mackenzie, Robert H. Moorman dan Richard Fetter. 1990. Transformational Leader Behaviors and Their Effects on Followers' Trust In Leader, Satisfaction, And Organizational Citizenship Behaviors, Leadership Quarterly, Vol 1, No 2, pp. 107-142.

Robbin, Stephen, P., (2003), Principles of Organizational Behavior: Custom Edition

Robbins, S. P. (2007). Organizational Behavior (10th Ed.).

Robbins, S. P., \& Judge, T. A. (2008). Organizational behaviour (13th Ed.). New Jersey: Pearson Education, Inc.

Rivai,Veithzal.2009. Manajemen Sumber Daya Manusia. Jakarta: PT. Raja Grafindo Persada.

Saleem, H. (2015). The impact of leadership styles on job satisfaction and mediating role of perceived organisational politics. Social and Behavioural Sciences, 172(2015), 563-569.

Schaubroeck, J., Lam, S. S. K., \& Peng, A. C. (2011). Cognition-based and affect-based trust as mediators of leader behavior influences on team performance. Journal of Applied Psychology, 96, 863-871, 
Schoorman, F.D., Mayer, R.C., \& Davis, J.H. (2007). An Integrative Model of Organizational Trust: Past, Present, and Future. Academy of Management Review, 32(2), 344-354.

Schindler, P. L., \& Thomas, C. C. (1993). The Structure of Interpersonal Trust In The Workplace. Psychological Reports, 73, 563-573.

Spector, P.E. (2012) Industrial and Organizational Psychology : Research and Practice (6th Ed.) Singapore : John Wiley \& Sons.

Suyono, Hadi. (2004). Perbedaan Sikap Terhadap Proses Pelaksanaan Otonomi Daerah Ditinjau Dari Tipe Kepemimpinan dan Budaya Organisasi, Indonesian Psychologycal Jurnal, Vol.1 January, pp 68-78.

Thamrin, H.M. (2012), The Influence of Transformational Leadership and Organizational Commitment on Job Satisfaction and Employee Performance, International Journal of Innovation, Management and Technology, Vol. 3 No. 5, pp. 566-572.

Tee, Elsadig Musa Ahmed, (2013). Impact of the relationship between transformational and traditional leadership styles on Iran's automobile industry job satisfaction, World Journal of Entrepreneurship, Management and Sustainable Development, Vol. 9 Issue: 1, pp.14-27

Voon, M. L., Lo, M. C., Ngui, K. S., \& Ayob, N. B. (2011). The influence of leadership styles on employees' job satisfaction in public sector organisations in Malaysia. International Journal of Business, Management, and Social Sciences, 2(1), 24-32.

Walumbwa, F. O., Orwa, B., Wang, P., \& Lawler, J. J. (2005). Transformational leadership, organizational commitment, and job satisfaction: A comparative study of Kenyan and U.S. financial firms. Human Resource Development Quarterly, 16, 235-256

Yang, J., \& Mossholder, K. W. (2010). Examining the effects of trust in leaders: A bases-and-foci approach. The Leadership Quarterly, 21, 50-63

Yaghoubipoor, Ali, Ong Puay Tee and Elsadig Musa Ahmed, 2013. Impact of The Relationship Between Transformational and Traditional Leadership Styles on Iran's Automobile Industry Job Satisfaction, World Journal of Entrepreneurship, Management and Sustainable Development, Vol. 9 No. 1, pp. 14-27

Yanik, Oktay. (2018). The Mediating Role of Trust in the Effect of Ethical Leadership Employee Attitudes and Behaviors, Journal of Business Research,Vol, No.1,pp. 447-464 
The Effect of Transformational Leadership Style... (Muslichah) 